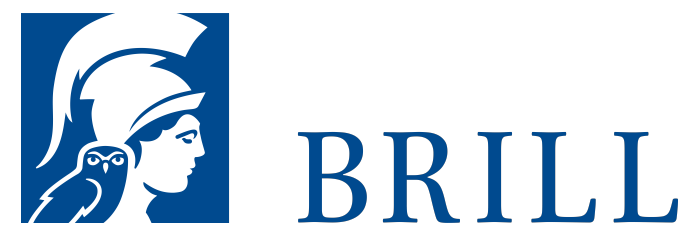

\title{
Gerechtfertigt durch Erfahrung?
}

John Henry Newmans conversion narratives und die Rolle von Luther und Augustinus in seiner Rechtfertigungslehre

Author: Thomas Möllenbeck

Newmans Lectures on the Doctrine of Justification sind vor dem Hintergrund seiner Apologia pro vita sua sowie seiner fiktiven conversion narratives Callista und Loss and Gain zu interpretieren, will man dem ökumenischen Potential seiner Rechtfertigungslehre in der Entgegensetzung von Luther und Augustinus gerecht werden.

John Henry Newmans berühmte Lectures on the Doctrine of Justification sind nicht nur eine Darstellung der

Rechtfertigungslehre, wie sie im Neuen Testament zu finden und in der anglikanischen Kirche gelehrt worden ist. Sie gilt auch für die römisch-katholische Kirche, da Newman sie nach seiner Konversion fast unverändert wieder veröffentlichen konnte. Die zentrale Intention, die Newman in ihr verfolgt, und die in der Forschung kontrovers diskutierte Rolle, die Martin Luther und Aurelius Augustinus in ihr spielen, hängen eng mit Newmans Vorstellung der christlichen Bekehrungserfahrung zusammen. Das wird deutlich, wenn man seine drei conversion narratives, die Apologia pro vita sua sowie seine zwei Romane Callista und Loss and Gain bei der Interpretation der Rechtfertigungslehre berücksichtigt.

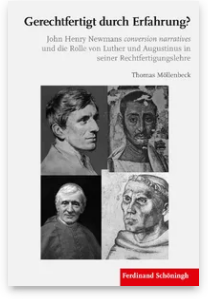

Pages: 598

Seiten

Language:

German

Subjects:

General,

Theology and

World

Christianity

Publisher: Brill |

Schöningh

E-Book (PDF)

Released online:

13 Dec 2017

ISBN: 978-3-

657-78642-8

List price

Hardback

Publication date:

o1 Dec 2017

ISBN: 978-3-

506-78642-5

List price 
Thomas Möllenbeck ist Dozent an der Phil.-Theol. Hochschule in Münster sowie am International Theological Institute in Trumau bei Wien. Zudem ist er Privatdozent an der KatholischTheologischen Fakultät der Universität Wien.

For more information see brill.com

$$
\begin{aligned}
& \text { Order information: Order online at brill.com } \\
& \text { +44 } 33 \circ 333 \text { o049 | customerservices@brill.com } \\
& \text { Submission information: brill.com/authors }
\end{aligned}
$$

Titles published by Brill | Fink, Brill | mentis or Brill| Schöningh: +49(o)71 5413279216 | brill@brocom.de 